\title{
Bird frugivory and seed germination of Myrsine umbellata and Myrsine lancifolia (Myrsinaceae) seeds in a cerrado fragment in southeastern Brazil
}

\author{
Rafael Soave Guerta ${ }^{1,5}$, Lucas Gustavo Lucon', José Carlos Motta-Junior', \\ Luís Augusto da Silva Vasconcellos ${ }^{3}$ \& Rodolfo Antônio de Figueiredo ${ }^{4}$ \\ ${ }^{1}$ Centro de Ciências Biológicas e Saúde, Universidade Federal de São Carlos - UFSCar, \\ Rod. Washington Luiz, Km 235, CEP 13565-905, São Carlos, SP, Brasil \\ ${ }^{2}$ Departamento de Ecologia, Laboratório de Ecologia de Aves - LABECOAVES, Instituto de Biociências, \\ Universidade de São Paulo - USP, CEP 05508-090, São Paulo, SP, Brasil \\ ${ }^{3}$ ENGEVIX Engenharia S. A, Rua da Assembléia, 66, CEP 20011-000, Rio de Janeiro, RJ, Brasil \\ ${ }^{4}$ Centro de Ciências Agrárias, Universidade Federal de São Carlos - UFSCar, \\ Rod. Anhanguera, Km 174, CEP 13600-970, Araras, SP, Brasil \\ ${ }^{5}$ Corresponding author: Rafael Soave Guerta, e-mail: rsguerta@yahoo.com.br
}

GUERTA, R.S., LUCON, L.G., MOTTA-JUNIOR, J.C., VASCONCELLOS, L.A.S. \& FIGUEIREDO, R.A. Bird frugivory and seed germination of Myrsine umbellata and Myrsine lancifolia (Myrsinaceae) seeds in a cerrado fragment in southeastern Brazil. Biota Neotrop. 11(4): http://www.biotaneotropica.org.br/v11n4/ en/abstract?article+bn00911042011

\begin{abstract}
Birds are known to be important dispersers of plants, since the passage of seeds through the digestive tract often has a positive influence on germination percentage and speed. In this study, proportions of germination in different substrates were compared between Myrsine (Myrsinaceae) seeds collected manually and those ingested by birds. The guilds of birds that fed on $M$. umbellata and M. lancifolia were identified and comprise 24 and 12 species, respectively. A higher germination proportion was found among seeds defecated by birds and sowed in the study area. The study also found differences between the guilds of frugivores in both synchronopatric species. Therefore, we suggest that $M$. umbellata and $M$. lancifolia are important food sources by birds that play a positive influence for enhance germination of Myrsine.

Keywords: zoochory, seed dispersal, Myrsine, frugivorous birds, Cerrado.
\end{abstract}

GUERTA, R.S., LUCON, L.G., MOTTA-JUNIOR, J.C., VASCONCELLOS, L.A.S. \& FIGUEIREDO, R.A. Frugivoria e germinação de sementes de Myrsine umbellata e Myrsine lancifolia (Myrsinaceae) por aves em um fragmento de Cerrado no sudeste do Brasil. Biota Neotrop. 11(4): http://www.biotaneotropica.org.br/ v11n4/pt/abstract?article+bn00911042011

Resumo: As aves são reconhecidamente importantes agentes dispersores de plantas, uma vez que a passagem da semente pelo trato digestório muitas vezes interfere positivamente na porcentagem e velocidade de germinação de sementes. No presente estudo, as porcentagens de germinação, em diferentes substratos, foram comparadas entre sementes ingeridas por aves e sementes não-ingeridas (coletadas manualmente) de Myrsine (Myrsinaceae). A guilda de aves que se alimentou de $M$. umbellata e M. lancifolia foi identificada com 24 e 12 espécies, respectivamente. Verificou-se maior porcentagem de germinação nas sementes defecadas por aves, que foram semeadas em solo da área de estudo. Além disso, constataram-se diferenças nas guildas de frugívoros entre as duas espécies sincronopátricas. Portanto, nós sugerimos que $M$. umbellata e M. lancifolia são importantes fontes alimentares para aves que têm uma influência positiva para o aumento na germinação de Myrsine.

Palavras-chave: zoocoria, dispersão de sementes, Myrsine, aves frugívoras, Cerrado. 


\section{Introduction}

Mechanisms of seed dispersal by animals have been the object of study for a long time (e.g. Corner 1949, van der Pijl 1969, Levey et al. 2002, Dennis et al. 2007). Among dispersers, birds and mammals play a key role in this process (Howe \& Smallwood 1982). Barnea et al. (1992) indicate that birds can increase the temporal and spatial distribution of ingested seeds thereby promoting their germination and the establishment of seedlings. The effects of seed ingestion are variable; it affects germination proportion, rate, and speed in different ways depending on the disperser species, even when researchers have studied closely related plant species and the same habitat (Barnea et al. 1990, Izhaki \& Safriel 1990, Traveset 1998, Traveset et al. 2001, Paulsen \& Högstedt 2002). In addition, the fruit pulp is known to contain chemicals that inhibit germination and its removal usually fosters the success of the embryo (Figueroa \& Castro 2002, Robertson et al. 2006). However, this effect is not uniform, nor is it applicable to all seeds dispersed by birds (Barnea et al. 1991).

Myrsinaceae comprises 40 genera, eight of which occur in Brazil, with roughly 70 species (Souza \& Lorenzi 2008). Among them, the genus Myrsine, which has Rapanea Aubl as principal synonymous (Freitas \& Carrijo 2010), popularly known as capororoca (Lorenzi 1992), has 26 species, distributed from the northeast to the south of Brazil (Freitas \& Carrijo 2010). The species Myrsine umbellata and $M$. lancifolia are synchronopatric in the region under investigation, fruiting between October and February. They are medium-sized trees that produce a large quantity of small globose purple drupes, odorless and tasteless to humans, with a thin pericarp and a hard testa seed (Lorenzi 1992, Ramos et al. 2008).

Eight Myrsine species have been studied with respect to the dispersal of their diaspores. Pineschi (1990) studied seven of them (M. acuminta, M. ferruginea, M. gardneriana, M. guyanensis, M. lineata, M. schwackeana, and M. villosissima) in the Atlantic Forest and Francisco \& Galetti (2001) studied M. lancifolia in the cerrado (Brazilian savanna) in São Carlos (São Paulo State). Both studies found birds as the main consumers and, thus, are potential disperses. Also in São Paulo State, Pascotto (2007) found most disperser (80.6\%) feeding on fruits of M. ferruginea in the edge of a riparian forest. The study conducted by Pineschi (1990) included germination tests with seeds ingested by birds. The author employed filter paper as substrate and found a low germination percentage $(8.4 \%)$, in agreement with other authors' findings (Joly \& Felippe 1979, Lorenzi 1992).

Taking into consideration the importance of Myrsine ssp. fruits to bird feeding reported in previous studies and the paucity of information on the quality of fruit dispersion in the literature, which mainly focuses on frugivory research, the purpose of this study was: 1) to survey the birds that feed on M. umbellata and M. lancifolia fruits in a cerrado fragment; and 2) assess the effects of passage through the digestive tract of disperser birds on the germination of seeds of two Myrsine species.

\section{Material and Methods}

The study was conducted in non-urban area located on the campus of Universidade Federal de São Carlos, in the central part of São Paulo State, Brazil ( $21^{\circ} 58^{\prime} \mathrm{S}$ and $\left.47^{\circ} 52^{\prime} \mathrm{W}\right)$. This area encompasses 124.68 ha of cerrado vegetation, 3.60 ha of riparian forest, 93.84 ha of Eucalyptus plantation with cerrado undergrowth, 222.73 ha of Eucalyptus spp. plantation, and 83.67 ha consisting of dams, tracks, and altered fields (Paese 1997), a total of 528.52 ha. The site has been relatively disturbed, with tracks and the presence of cyclists principally at weekends, and affected by occasional fires. At $850 \mathrm{~m}$ above sea level, the regional climate is warm temperature with dry winter occurring between April to September and wet summer from October to March; the mean temperature is around $21^{\circ} \mathrm{C}$, and the annual precipitation lies between 1,138 and 1,593 $\mathrm{mm}$ (Valenti et al. 2008).

Motta-Junior \& Vasconcellos (1996) and Francisco \& Galetti (2001) found 223 bird species at the studied site, $33 \%$ of which feed on fruits at least sporadically. Therefore, it is possible that a significant quantity of the seeds in the area is dispersed by birds.

Field observations occurred from 6:00 AM and 6:00 PM in six M. umbellata specimens (three in 1986, 1988 and three plants between 2007-2008) and two M. lancifolia specimens in 2007 and 2008 (Figure 1a,b), located in a transition area between a secondary cerrado forest and a riparian forest. The first species was observed between November and December 1986 and January 1988 (24.5 hours of observations), and in December 2007 and January 2008 (30 hours of study), while the second species was observed for 25 hours between December 2007 and January 2008. Observations were done when specimens were at their fruiting peak. The usual length fruiting period in the study area for Myrsine is September to March.

Observation was performed at a distance of 10 to $15 \mathrm{~m}$ from the trees. The birds were identified by their morphology and/or vocalization and, when necessary, with the aid of field guides. During the observations there were recorded the frugivorous species, the time of their visits, the number of fruits eaten, the pattern of fruit manipulation and length of stay in the tree for each bird. Agonistic encounters (direct lunges, there being no physical contact necessarily) were also registered.

There were collected all bird excreta found in a 2 meter-wide track between the cerrado and the riparian forest, falling perpendicularly from the Myrsine specimens towards the same and up to $50 \mathrm{~m}$ from them, in addition to those occasionally found in others tracks near the specimens (Figure 1c). These feces were identified as having been defecated by birds due to the presence of uric acid in them. In the laboratory, seeds were sorted from the excreta.

Germination tests were performed as described by Figueiredo \& Perin (1995). In December 2007, 300 Myrsine seeds from roughly 60 bird feces were randomly collected as well as 300 seeds directly from the branches of four trees, two of each species (control seeds), which, after being mechanically removed from the pulp, were washed for 1 hour in tap water so as to eliminate germination-inhibiting substances, and sowed on filter paper in a gerbox. Three replicates were done for 100 seeds, which were kept under natural temperature and lighting conditions and at a constant humidity level in the gerbox. Following the same procedure, 600 seeds (300 control seeds and 300 dispersed seeds) were collected in 2007, which were then sowed in soil from the area under investigation, transported to the laboratory.

As it was not possible to identify the seeds at the species level, dispersed as well as control seeds were grouped in the same germination tests, which thus verified, indistinctively, the germination rate for all Myrsine species (Figure 1d).

In 1986, germination tests were carried out with 450 Myrsine seeds: 150 seeds excreted by birds, 150 control seeds (mechanically removed pulp), and 150 seeds with intact pulp. Laboratory tests were performed on filter paper under natural temperature and lighting conditions and at constant humidity.

In both different experiments, the seeds were monitored for 5 months after sowing, with no additional treatment to prevent contamination from fungi and other microorganisms so as to reproduce the conditions found in the area in question. The statistical analysis of the 2007 test results was done by means of variance analysis (single factor ANOVA) and chi-square test $\left(\chi^{2}\right)$ in order to verify differences among replicates and treatments. The 1986 test results were compared by means of chi-square test $\left(\chi^{2}\right)$. 

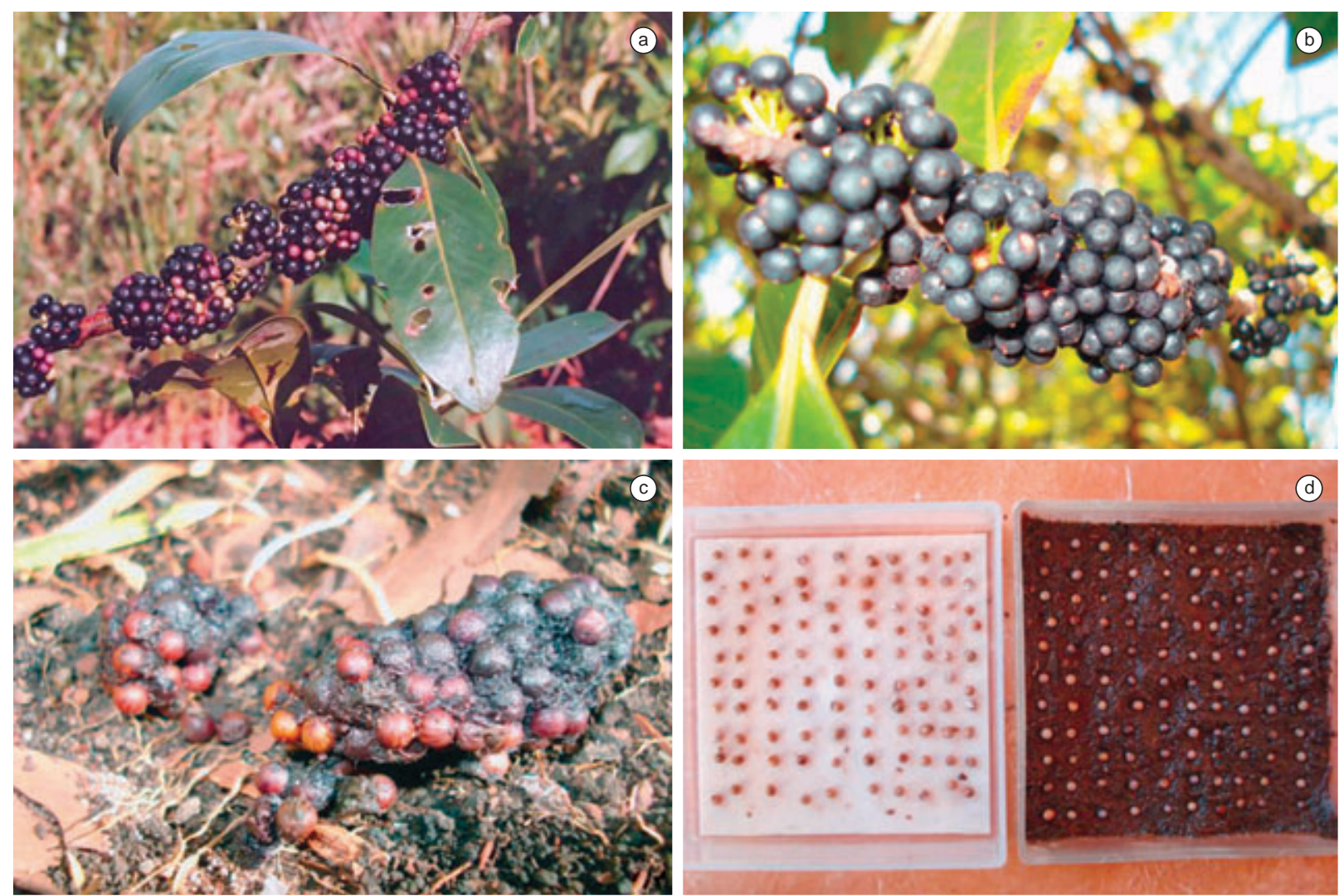

Figure 1. Studied plant species. a) Myrsine umbellata. ( J. C. Motta-Junior; b) Myrsine lancifolia; c) Seeds defecated by birds; d) Germination tests with filter paper and soil from the study area. (C) R. A. Figueiredo.
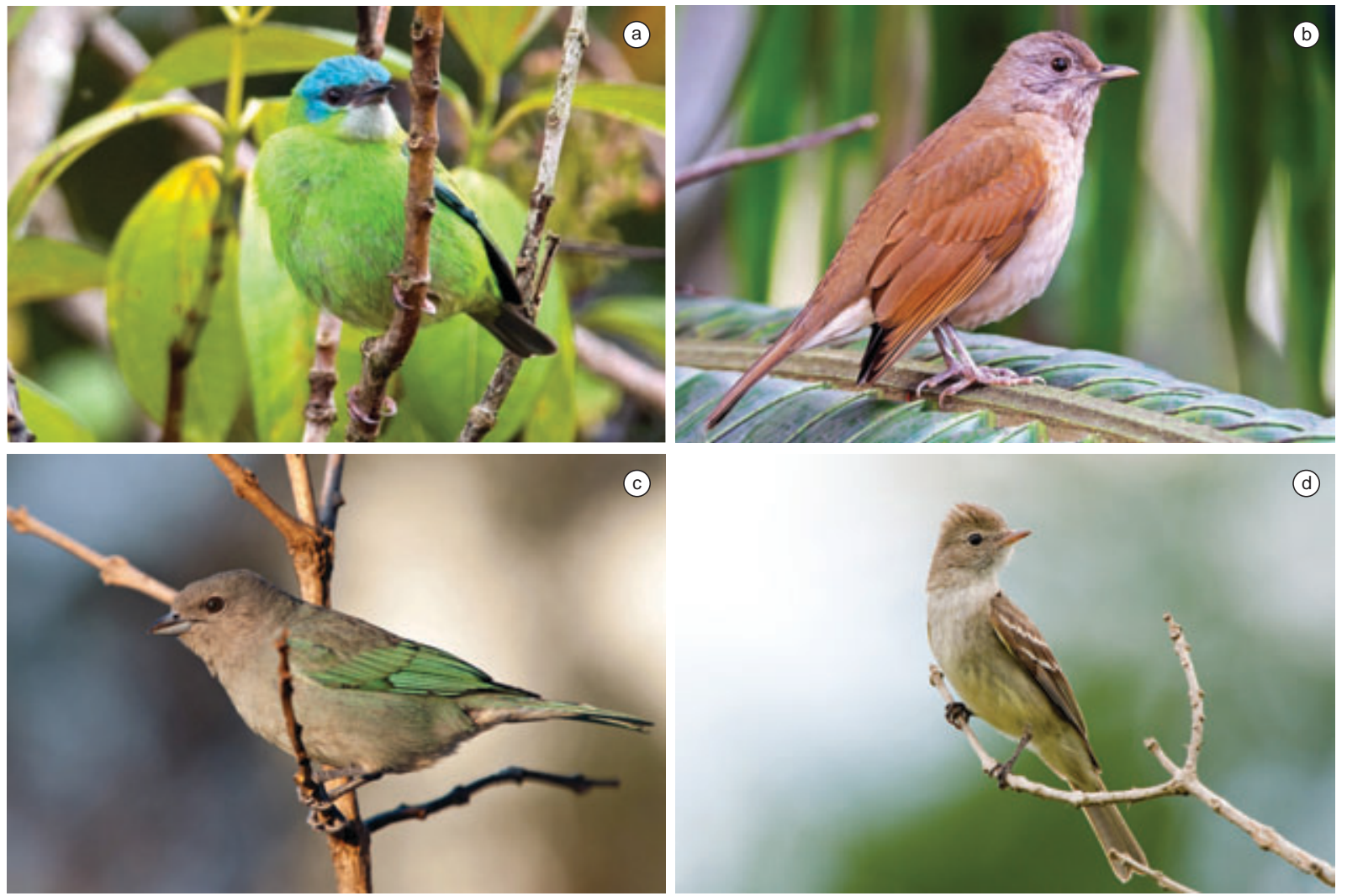

Figure 2. Some birds recorded in this study. a) Female Blue Dacnis (Dacnis cayana), the most frequent visitor among the visitors of Myrsine lancifolia, during 2007/08 observations; b) Pale-breasted Thrush (Turdus leucomelas), fed of Myrsine umbellata during the two periods of this study and consumed the highest of number of fruits during the 86/88 period; c) Sayaca Tanager (Thraupis sayaca) visited the two species of Myrsine spp.; d) Lesser Elaenia (Elaenia chiriquensis), migrant living in the study area during spring and summer. () J. C. Motta-Junior. 
Guerta, R.S. et al.

Table 1. Bird species that fed on Myrsine umbellata in November-December 1986 and January 1988 (a), from December 2007 to January 2008 (b) and Myrsine lancifolia from December 2007 to January 2008 (c), in São Carlos, SP, with total number of visits, total number of consumed fruits, diet and migratory status (M.S.). Nomenclature according to CBRO (Comitê... 2011). Diet and migration according to Motta-Junior (1990) and Motta-Junior \& Vasconcellos (1996).

\begin{tabular}{|c|c|c|c|c|c|}
\hline Family/species & $\begin{array}{c}\text { Total number of } \\
\text { visits }\end{array}$ & $\begin{array}{l}\text { Total of consumed } \\
\text { fruits }\end{array}$ & $\begin{array}{c}\text { Consumed fruits per } \\
\text { visit }\end{array}$ & Diet * & M.S.** \\
\hline \multicolumn{6}{|l|}{ Myrsine umbellata (a) } \\
\hline \multicolumn{6}{|l|}{ Picidae } \\
\hline Colaptes melanochloros & 15 & 256 & 17 & INS & $\mathrm{R}$ \\
\hline \multicolumn{6}{|l|}{ Pipridae } \\
\hline Antilophia galeata & 1 & 2 & 2 & FRU & $\mathrm{R}$ \\
\hline Chiroxiphia caudata & 2 & 4 & 2 & FRU & $\mathrm{R}$ \\
\hline \multicolumn{6}{|l|}{ Tityridae } \\
\hline Pachyramphus validus & 1 & 30 & 30 & INS & M \\
\hline \multicolumn{6}{|l|}{ Tyrannidae } \\
\hline Elaenia chiriquensis (Figure 2d) & 13 & 102 & 7,8 & ONI & M \\
\hline Elaenia flavogaster & 14 & 58 & 4,1 & ONI & $\mathrm{R}$ \\
\hline Elaenia mesoleuca & 10 & 24 & 2,4 & ONI & M \\
\hline Elaenia obscura & 13 & 82 & 6,3 & ONI & $\mathrm{R}$ \\
\hline Elaenia spp. & 23 & 72 & 3,1 & ONI & $\mathrm{R}$ \\
\hline Empidonomus varius & 2 & 8 & 4 & INS & M \\
\hline Myiarchus ferox & 1 & 2 & 2 & INS & $\mathrm{R}$ \\
\hline Myiozetetes similis & 2 & 6 & 3 & ONI & $\mathrm{R}$ \\
\hline Pitangus sulphuratus & 4 & 20 & 5 & ONI & $\mathrm{R}$ \\
\hline Tyrannus melancholichus & 4 & 14 & 3,5 & INS & M \\
\hline Tyrannus savanna & 1 & 4 & 4 & INS & M \\
\hline \multicolumn{6}{|l|}{ Vireonidae } \\
\hline Vireo olivaceus & 33 & 130 & 3,9 & ONI & M \\
\hline \multicolumn{6}{|l|}{ Turdidae } \\
\hline Turdus rufiventris & 30 & 366 & 12,2 & ONI & $\mathrm{R}$ \\
\hline Turdus amaurochalinus & 58 & 490 & 8,4 & ONI & $\mathrm{R}$ \\
\hline Turdus leucomelas & 47 & 580 & 12,3 & ONI & $\mathrm{R}$ \\
\hline \multicolumn{6}{|l|}{ Thraupidae } \\
\hline Dacnis cayana & 14 & 30 & 2,1 & ONI & $\mathrm{R}$ \\
\hline Tangara cayana & 3 & 3 & 1 & ONI & $\mathrm{R}$ \\
\hline Thraupis sayaca & 2 & 4 & 2 & ONI & $\mathrm{R}$ \\
\hline \multicolumn{6}{|l|}{ Myrsine umbellata (b) } \\
\hline \multicolumn{6}{|l|}{ Tyrannidae } \\
\hline Elaenia flavogaster & 5 & 18 & 3,6 & ONI & $\mathrm{R}$ \\
\hline Empidonomus varius & 1 & 3 & 3 & INS & M \\
\hline \multicolumn{6}{|l|}{ Vireonidae } \\
\hline Vireo olivaceus & 19 & 135 & 7,1 & ONI & M \\
\hline \multicolumn{6}{|l|}{ Turdidae } \\
\hline Turdus leucomelas & 3 & 29 & 9,7 & ONI & $\mathrm{R}$ \\
\hline \multicolumn{6}{|l|}{ Thraupidae } \\
\hline Tangara cayana & 1 & 6 & 6 & ONI & $\mathrm{R}$ \\
\hline Dacnis cayana & 6 & 45 & 7,5 & ONI & $\mathrm{R}$ \\
\hline Thraupis sayaca (Figure 2c) & 4 & 16 & 4 & ONI & $\mathrm{R}$ \\
\hline Tersina viridis & 1 & 4 & 4 & ONI & $\mathrm{R}$ \\
\hline Ramphocelus carbo & 1 & 30 & 30 & ONI & $\mathrm{R}$ \\
\hline
\end{tabular}

*FRU = frugivore, $\mathrm{INS}=$ insectivore, $\mathrm{ONI}=$ omnivore; $* * \mathrm{R}=$ resident, $\mathrm{M}=$ migratory. 
Table 1. Continued...

\begin{tabular}{|c|c|c|c|c|c|}
\hline Family/species & $\begin{array}{c}\text { Total number of } \\
\text { visits }\end{array}$ & $\begin{array}{c}\text { Total of consumed } \\
\text { fruits }\end{array}$ & $\begin{array}{c}\text { Consumed fruits per } \\
\text { visit }\end{array}$ & Diet * & M.S.** \\
\hline \multicolumn{6}{|l|}{ Myrsine lancifolia (c) } \\
\hline \multicolumn{6}{|l|}{ Tyrannidae } \\
\hline Elaenia spp. & 4 & 31 & 7,7 & ONI & $\mathrm{R}$ \\
\hline Elaenia flavogaster & 1 & 5 & 5 & ONI & $\mathrm{R}$ \\
\hline Myiarchus ferox & 1 & 21 & 21 & INS & $\mathrm{R}$ \\
\hline Hemitriccus margaritaceiventer & 1 & 5 & 5 & INS & $\mathrm{R}$ \\
\hline \multicolumn{6}{|l|}{ Vireonidae } \\
\hline Vireo olivaceus & 3 & 12 & 4 & ONI & M \\
\hline \multicolumn{6}{|l|}{ Corvidae } \\
\hline Cyanocorax cristatellus & 1 & 15 & 15 & ONI & $\mathrm{R}$ \\
\hline \multicolumn{6}{|l|}{ Turdidae } \\
\hline Turdus amaurochalinus & 4 & 86 & 21,5 & ONI & $\mathrm{R}$ \\
\hline \multicolumn{6}{|l|}{ Thraupidae } \\
\hline Dacnis cayana & 6 & 91 & 15,2 & ONI & $\mathrm{R}$ \\
\hline Thraupis sayaca & 1 & 9 & 9 & ONI & $\mathrm{R}$ \\
\hline Tersina viridis & 1 & 13 & 13 & ONI & $\mathrm{R}$ \\
\hline Tachyphonus coronatus & 1 & 3 & 3 & ONI & $\mathrm{R}$ \\
\hline Ramphocelus carbo & 1 & 10 & 10 & ONI & $\mathrm{R}$ \\
\hline
\end{tabular}

*FRU $=$ frugivore, $\mathrm{INS}=$ insectivore, $\mathrm{ONI}=$ omnivore; $* * \mathrm{R}=$ resident, $\mathrm{M}=$ migratory.

\section{Results}

The 1986 and 1988 observations of M. umbellata (Table 1) indicated 22 bird species feeding on its fruit, a total of 293 visits and 2,287 eaten fruits at 11.95 visits per hour. During this period, Turdus spp., Elaenia spp. and Vireo olivaceus were the most recurrent bird species, which made up 46, 24.9 and $11.2 \%$ of the visits, respectively. The 2007/2008 observations of $M$. umbellata indicated nine bird species, a total of 41 visits (Table 1) with 1.36 visits per hour. The most frequent bird was Vireo olivaceus: $46.3 \%$ of the visits.

Myrsine lancifolia specimens observed in 2007/2008 were visited by 12 bird species, totaling 25 feeding bouts (Table 1 ), at a rate of $1.0 \mathrm{visit} / \mathrm{h}$. Dacnis cayana was the most frequent, with $24 \%$ of visits (Table 1) (Figure 2a).

Two agonistic encounters were recorded during observations of M. lancifolia. One visitor, Dacnis cayana, was sent off by another visitor, Turdus amaurochalinus, while feeding on the fruits. The latter bird ate about 15 fruits and remained on the tree fruit for 1.5 minutes. During this time, one individual of Vireo olivaceus landed on the tree and, upon being attacked by T. amaurochalinus, both flew away.

The tests conducted with Myrsine in 1986 indicated the germination of 73 seeds defecated by birds (48.7\%) and 70 control seeds $(46.7 \%)$. The seeds with intact pulp did not germinate. There was no significant difference in germination between control seeds and those ingested by birds $\left(\chi^{2}=0.04, \mathrm{P}=0.83\right.$, df $\left.=1\right)$. In tests conducted with filter paper as substrate in 2007 , there was no significant difference in germination between control seeds $(4.67 \pm 0.57)$ and those ingested by birds $(3.67 \pm 1.53)(\mathrm{F}=1.13$, $\mathrm{P}=0.35, \mathrm{df}=1)$. In the test with soil from the study site as substrate there was a significant difference in germination between control seeds $(9.33 \pm 0.58)$ and those ingested by birds $(51.67 \pm 3.79)$ $(\mathrm{F}=366.57, \mathrm{P}<0.001, \mathrm{df}=1)$. Overall, the number of germinated seeds in soil was significantly larger than that of germinated seeds sown on filter paper $\left(\chi^{2}=27.43, \mathrm{P}<0.001, \mathrm{df}=1\right)$.

\section{Discussion}

Species feeding on M. umbellata recorded in 2007/2008 (Table 1) belong to four families and are classified as omnivores, whereas the guild recorded for the same species in 1986/1988 was composed of 22 species belonging to seven families, including Picidae, Pipridae, and Tytiridae (Table 1). The landscape alteration, due to new buildings and Eucalyptus spp. plantations, that occurred in between the two observation periods may have affected frugivores, especially the families that were absent in $2007 / 2008$. However, this reduction should not be seen as absolute, since other variables could have had an effect on this difference, e.g., more abundant fruits in this area during the observation period of two decades ago and/or observed plants more favorably positioned for the birds in question. Moreover, sampling efforts and observers were different in 1986/1988 and 2007/2008.

The number of frugivorous species recorded for M. lancifolia in 2007/2008 was similar to that observed by Francisco \& Galetti (2001). However, the rate of visits per hour in our study (1.0) was lower than that reported by the aforementioned authors, i.e., 3.31 visits per hour (202 birds, altogether). These authors reported three species, Turdus leucomelas (Figure 2b), Elaenia sp., and Colaptes melanochloros as the main frugivores, responsible for the removal of $80 \%$ of all fruits. Whereas the observations conducted in our study (2007/2008) pointed to Dacnis cayana as the most frequent visitor, accounting for $30.2 \%$ of all fruits removed, followed by T. amaurochalinus $(28.6 \%)$. The other species together accounted for $41.2 \%$ of fruit removal (Table 1 ).

The predominance of omnivorous birds was verified in all observations carried out at the study site. Francisco \& Galetti (2001) reported that omnivorous birds were responsible for $68 \%$ of all M. lancifolia fruits eaten, followed by insectivorous species (29\%). Observations of our study indicated that omnivorous birds ate $91.36 \%$ (275) and insectivorous species removed 8.64\% (26) of the 
M. lancifolia fruits. With respect to $M$. umbellata, omnivorous birds ate $86 \%$ of the fruits $(1,967)$ in $1986 / 1988$, followed by insectivorous species: $13.73 \%$ (314). The two exclusively frugivorous species, i.e., Antilophia galeata and Chiroxiphia caudata, contributed just $0.08 \%$ (2) and $0.17 \%$ (4), respectively. In 2007/2008, the proportion of M. umbellata fruits eaten by omnivores rose to $98.9 \%$ (283). The remainder (3) was eaten by only one insectivorous species: Empidonomous varius.

Although almost all large and specialized frugivores are extinct or very rare in the study area (Motta-Junior \& Vasconcellos 1996, Francisco et al. 2007), Myrsine spp. fruits are small and frequently eaten by generalist birds, with nutritive importance for omnivorous and insectivorous as previously detailed (Francisco \& Galetti 2001, this study), which present short-stay behavior. This fact, as observed in other plants studied in the same area (Francisco \& Galetti 2002a,b, Francisco et al. 2007, Silva et al. 2008), increases the chances of their being dispersed far away from parent plants, where predation and competition, tend to be lower (Janzen 1970, Howe \& Smallwood 1982, Howe et al. 1985).

Agonistic interactions may inhibit fruit consumption and seed dispersion by birds (Francisco \& Galetti 2001). However, only two records of agonistic encounters occurred in M. lancifolia, involving three main dispersers of this species, as recorded by Francisco \& Galetti (2001). This low number of agonistic interactions may be explained by the abundance of fruits produced per specimen (e.g. Willis 1966) as well as the availability of other resources in the area (Pascotto 2007).

Pineschi (1990) conducted germination tests with Myrsine spp. seeds using only filter paper as substrate and found a very low germination rate $(8.4 \%)$, which was confirmed in our study for tests using control seeds and filter paper as substrate. That author found that none of the 300 control seeds germinated and bird-defecated seeds germinated for only three species (4 out of $10 \mathrm{M}$. lineata seeds; 2 out of 10 M. gardneriana seeds, and 2 out of 35 M. schwackeana seeds). Similar to these species, the number of germinated Myrsine spp. seeds in this study, whereas was not possible identify the seeds at the species level, also indicates that passage through the digestive tract of birds fosters seed germination. Additional tests are importants to investigate the response of that passage through the digestive tract of birds have on each Myrsine' species of the study area.

Figueiredo \& Perin (1995) found differences between germination rates of Ficus spp. seeds sown on filter paper and soil and showed that the closer to natural conditions, the more accurate germination tests become, which was also verified in this work. Thus, although germination of seeds of the genus Myrsine is low, the germination response is better when they pass through the digestive tract of birds and when sown in soil from the study area. Futhermore, the highest proportion of germination in soil, as compared to filter paper, for defecated seeds may be related to some of soil characteristics, such as temperature variation and presence of chemical substances and/or microorganisms, as suggested by Figueiredo \& Perin (1995). These different patterns show that germination can be affected by factors associated with both disperser and substrate. Moreover, studies with other plant species indicate that the germination rate is not affected, or may even improve, when seeds are sown in soil (Barnea et al. 1990, 1991, Mangan et al. 2010). Future studies should concentrate in detail the environmental factors that influence germination, in order to clarify their action mechanisms.

Therefore, we suggest that $M$. umbellata and M. lancifolia are important food sources by birds that play a positive effect enhancing germination of Myrsine. Nevertheless, in order to better establish the above mentioned conclusions, further experiments need to be carried out. As suggested by Jordano \& Schupp (2000), for similar assemblages of frugivorous birds, which was also verified in this work, the seed disperser effectiveness is related to feeding and fruit handling behaviors and post-foraging patterns of habitat use. The observations of these components, as well as, total fruit production by plants and the percentage of that fall under parent trees are stimulated (e.g. Schupp 1993, Pizo 1997, Christianini \& Oliveira 2009).

\section{Acknowledgements}

Alice Moralez de Figueiredo for help in germination tests, Luis Carlos Bernacci (IAC) and Maria Inês Salgueiro Lima (Botany Department, UFSCar) for help in identifying plant species, and two anonymous reviewers for providing valuable comments and suggestions that improved an earlier version of the paper.

\section{References}

BARNEA, A., YOM-TOV, Y. \& FRIEDMAN, J. 1990. Differential germination of two closely related species of Solanum in response to bird ingestion. Oikos 57: 222-228.

BARNEA, A., YOM-TOV, Y. \& FRIEDMAN, J. 1991. Does ingestion by birds affect seed germination? Funct. Ecol. 5: 394-402.

BARNEA, A., YOM-TOV, Y. \& FRIEDMAN, J. 1992. Effect of frugivorous birds on seed dispersal and germination of multi-seeded fruits. Acta Oecol. 13(2): 209-219.

CBRO 2011. http://www.cbro.org.br/CBRO/listabr.htm (accessed in 04/05/2011).

CHRISTIANINI A.V. \& OLIVEIRA P.S., 2009. The relevance of ants as seed rescuers of a primarily bird-dispersed tree in the Neotropical cerrado savanna. Oecologia 160: 735-745.

CORNER, E. J. H. 1949. The durian theory of the origin of the modern tree. Ann. Bot. 13(4): 367-414.

DENNIS A. J., GREEN, R., SCHUPP, E. W. \& WESCOTT, D., (eds) 2007. Frugivory and seed dispersal: theory and applications in a changing world. Wallingford, UK: CAB International.

FIGUEIREDO, R. A. \& PERIN, E. 1995. Germination ecology of Ficus luschnathiana drupelets after bird and bat ingestion. Acta Oecol. 16(1): 71-75.

FIGUEROA, J. A. \& CASTRO, S. A. 2002. Effects of bird ingestion on seed germination of four woody species of the temperate rainforest of Chiloé island, Chile. Plant Ecol. 160: 17-23.

FRANCISCO, M. R. \& GALETTI, M. 2001. Frugivoria e dispersão de sementes de Rapanea lancifolia (Myrsinaceae) por aves numa área de cerrado do Estado de São Paulo, sudeste do Brasil. Ararajuba 9(1): 13-19.

FRANCISCO, M. R. \& GALETTI, M. 2002a. Aves como potenciais dispersoras de sementes de Ocotea pulchella Mart. (Lauraceae) numa área de vegetação de cerrado do sudeste brasileiro. Revista Brasileira de Botânica 25(1):11-17.

FRANCISCO, M. R. \& GALETTI, M. 2002b. Consumo dos frutos de Davilla rugosa (Dilleniaceae) por aves numa área de cerrado em São Carlos, Estado de São Paulo. Ararajuba 10(2): 193-198.

FRANCISCO, M. R. LUNARDI, V.O. \& GALETTI, M. 2007. Bird attributes, plant characteristics, and seed dispersal of Pera glabrata (Schott, 1858), (Euphorbiaceae) in a disturbed cerrado area. Brazilian Journal of Biology, 67(4): 627-634.

FREITAS, M. F. \& CARRIJO, T. T. 2010. http://floradobrasil.jbrj.gov.br/2010/ (accessed in 04/05/2011).

HOWE, H. F. \& SMALLWOOD, J. 1982. Ecology of seed dispersal. Ann. Rev. Ecol. Syst. 13: 201-28.

HOWE, H.F., SCHUPP, E.W. \& WESTLEY, L.C. 1985. Early consequences of seed dispersal for a neotropical tree Virola surinamensis. Ecology 66(3): 781-791.

IZHAKI, I. \& SAFRIEL, U. N. 1990. The effect of some Mediterranean scrubland frugivores upon germination patterns. J. Ecol. 78(1): 56-65. 
JANZEN, D. H., 1970. Herbivores and the number of tree species in tropical forests. Am. Nat., 104: 501-528.

JORDANO, P. \& SCHUPP, E.W. 2000. Seed disperser effectiveness: the quantity component and patterns of seed rain for Prunus mahaleb. Ecological Monographs 70(4): 591-615.

JOLY, C. A. \& FELIPPE, G. M. 1979. Dormência das sementes de Rapanea guianensis Aubl.. Revista Brasileira de Botânica 2(1): 1-6.

LEVEY, D. J., SILVA, W. R., \& GALETTI, M. (eds) 2002. Seed dispersal and frugivory: ecology, evolution and conservation. Wallingford, UK: $\mathrm{CAB}$ International.

LORENZI, H. 1992. Árvores Brasileiras: manual de identificação e cultivo de plantas arbóreas nativas do Brasil. Nova Odessa: Editora Plantarum.

MANGAN, S. A., SCHNITZER, S. A., HERRE, E. A., MACK, K. M. L., VALENCIA, M. C., SANCHEZ, E. I. \& BEVER, J. D. 2010. Negative plant-soil feedback predicts tree-species relative abundance in a tropical forest. Nature 466: 752-755.

MOTTA-JUNIOR, J.C. 1990. Estrutura trófica e composição das avifaunas de três hábitats terrestres na região central do estado de São Paulo. Ararajuba1:65-71.

MOTTA-JUNIOR, J. C. \& VASCONCELLOS, L. A. S. 1996. Levantamento de aves do campus da Universidade Federal de São Carlos, estado de São Paulo, Brasil. Anais do Seminário Regional de Ecologia 7: 159-171.

PAESE, A. 1997. Caracterização e análise ambiental do campus da Universidade Federal de São Carlos (UFSCar), São Carlos, SP. Dissertação de Mestrado, Universidade Federal de São Carlos, São Carlos.

PASCOTTO, M. C. 2007. Rapanea ferruginea (Ruiz \& Pav.) Mez. (Myrcinaceae) como uma importante fonte alimentar para as aves em uma mata de galeria no interior do Estado de São Paulo. Revista Brasileira de Zoologia 24(3): 735-741.

PAULSEN, T. R. \& HÖGSTEDT, G. 2002. Passage through bird guts increases germination rates and seeding growth in Sorbus aucuparia. Funct. Ecol. 16: 608-616.
PINESCHI, R. B. 1990. Aves como dispersores de sete espécies de Rapanea (Myrsinaceae) no maciço do Itatiaia, estados do Rio de Janeiro e Minas Gerais. Ararajuba 1: 73-78.

PIZO, M.A. 1997. Seed dispersal and predation in two populations of Cabralea canjerana (Meliaceae) in the Atlantic Forest of southeast Brazil. Journal of Tropical Ecology 13: 559-578.

RAMOS, V. S., DURIGAN, G., FRANCO, G. A. D. C., SIQUEIRA, M. F. \& RODRIGUES, R. R. 2008. Árvores da floresta estacional semidecidual: guia de identificação de espécies. São Paulo: Edusp/Biota-Fapesp.

ROBERTSON, A. W., TRASS, A., LADLEY, J. J. \& KELLY, D. 2006. Assessing the benefits of frugivory for seed germination: the importance of the deinhibition effect. Funct. Ecol. 20: 58-66.

SCHUPP, E.W., 1993. Quantity, quality and the effectiveness of seed dispersal by animals. Vegetatio. 107-108: 15-29.

SILVA, I. A., FIGUEIREDO, R. A. \& MATOS, D. M. S. 2008. Feeding visit time of fruit-eating birds in Cerrado plants: revisiting the predation risk model. Revista Brasileira de Zoologia 25(4): 682-688.

SOUZA, V. C. \& LORENZI, H. 2008. Botânica Sistemática: guia ilustrado para identificação das famílias de fanerógamas nativas e exóticas no Brasil, baseado em APGII. Nova Odessa: Plantarum.

VALENTI, M.W., CIANCIARUSO, M.V. \& BATALHA, M.A. 2008. Seasonality of litterfall and leaf decomposition in a cerrado site. Brazilian journal of Biology 68(3): 459-465.

TRAVESET, A. 1998. Effect of seed passage through vertebrate frugivores' guts on germination: a review. Perspectives in Plant Ecology, Evolution and Systematics 1/2: 151-190.

TRAVESET, A., RIERA, N. \& MAS, E. 2001. Passage through bird guts causes interspecific differences in seed germination characteristics. Funct. Ecol. 15: 669-675.

van der PIJL, L. 1969. Principles of dispersal in higher plants. New York: Springer-Verlag.

WILLIS, E. O. 1966. Competitive exclusion and birds at fruiting trees in Western Colombia. The Auk 83:479-480. 
